\title{
Post-Glacial Forests Investigated by SMNH Field Parties
}

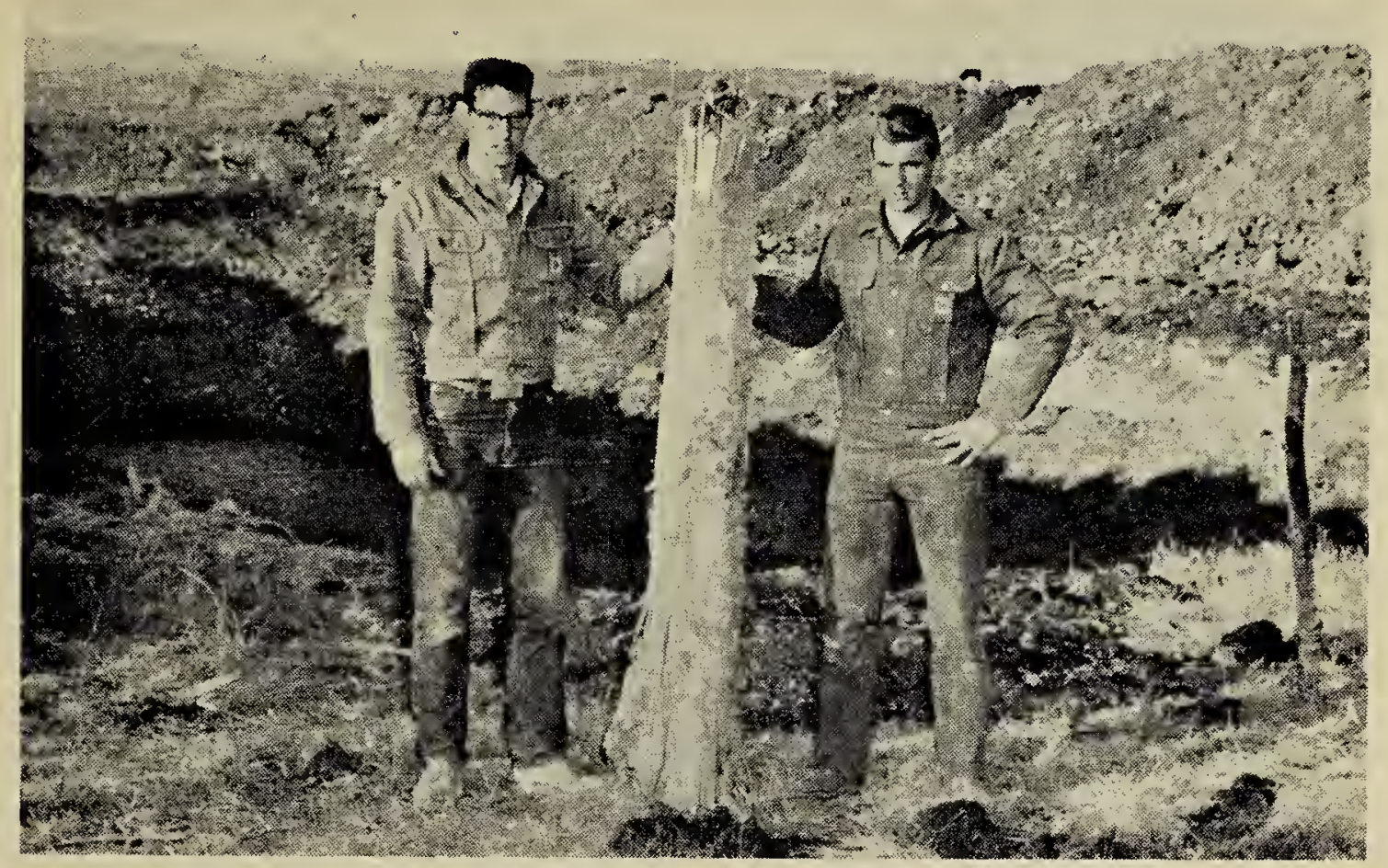

Saskatchewan Museum of Natural History Photo

Kenneth and Vernon Sapergia with tree remains found while digging a dugout at Lillestrom, 20 miles southwest of Moose Jaw.

The excavation of farm "dugouts" has turned up a fascinating amount of post-glacial forest material. Several yeais ago (October, 1958) on Jack Scrimbit's farm at Kayville, Saskatchewan, contractors found a buried log in a 12-foot dugout excavation and their discovery brought a party from the Saskatchewan Museum of Natural History to investigate (see Blue Jay, 17:20-21). A find somewhat similar to the "Scrimbit Forest" had previously been unearthed (in 1940) in a peat bog near Herbert, where material was found carbon lated at $10,050 \pm 300$ years. At Kayville, the dates ranged from 10,400 years for the top level at eleven feet, eight inches, to 11,700 years for the lower level at 206 inches. Following the Kayville find, an encouraging number of other reports carne to the Museum regarding both old and new finds.

This year several other finds of post-glacial forest have been investigated by the Museum. In September, 1961, a farm dugout near Earl Grey, 40 miles north of Regina, yielded extremely well-preserved remains that were reported to the Museum by the farmer, Wilfred Manz. At a depth of about 12 feet (as in the Kayville dugout) aged specimens of wood, other vegetation, and animal life were unearthed.

Later in the season, three more sites were found-at Lillestrom, Mortlach and Chipperfield. Again, all these discoveries were made by farmers excavating cattle-watering dugouts. At Lillestrom, material recovered incluaded a six-foot section of a tree (see photo), two particularly well-preserved skeletons of fish, leaves, insects, seeds and cones. These materials were recovered at a depth of 10 to 16 feet, under a layer of inorganic pond sediment. B. A. McCorquodale, Curator of Paleontology at the Museum, explains that the deposicion of a largely inorganic layer over the organic layer reflects a climactic change which took place about 10,000 years ago.

The discovery on Roy Carter's farm at Mortlach and that reported by $\mathrm{W}$. Marjerrison on a farm at Chipperfield revealed similar materials. Age estimates on these finds are based on the carbon 14 tests on the Kayville materials. All such reports are welcomed by the Museum in plotting the range of post-glacial forest in the province. 